\title{
DEATH PRACTICES IN THE NORTH WEST OF AUSTRALIA
}

\author{
Jack Bohemia and William McGregor
}

\section{Introduction 1}

All human societies have rites and taboos surrounding death. In mainstream Australian society, for instance, the dead are disposed of in rites of the funeral, either by burial or cremation. And there is a taboo - which usually lasts for some weeks or months - on mentioning the words 'dead', 'death', 'die' (and many others such as 'kick the bucket', 'croak') to, or in the presence of close relatives of the dead; this taboo is particularly strong in reference to the dead person, who 'passes away'.

In traditional times, Australian Aboriginal societies had their own unique, highly developed and elaborate death rites and taboos. Quite a lot is known about them, as they have enjoyed a prominent place in anthropological studies, which usually include a full chapter on the rites of death. ${ }^{2}$ Accounts such as these are 'normally' pieced together from information gleaned from a variety of quite disparate sources, including, primarily, other anthropological works, participant observation, and interviews with Aboriginal people. In doing this, the anthropologist acts as a bricoleur, weaving together his or her coherent and (hopefully) intemally consistent account from the materials available to him/her.

One may well wonder how Aborigines themselves understand, conceptualise, and speak about their own rites and taboos of death. Do they see the same events as most significant, and most worthy of being spoken about? Do they understand, and represent particular events associated with death in the same, or similar ways to the ways attributed to them by anthropologists? Do they invest the same significance in these events? Having asked these questions, we might proceed to ask, where there are differences in opinion, interpretation, or 'facts', which is the more reliable, or which is the truth, or a better representation of the truth? These issues of verisimilitude are not of particular interest to us in the present

Jack Bohemia was born on Old Bohemia station around the turn of the century. He worked for many years as a stockman on that station and many others in the region, and as a police tracker. He is best known for his involvement in the apprehension of Banjo, the so called Aboriginal 'outlaw' who 'allegedly' killed two white men on Billiluna station in 1922. In 1972 Bohemia was awarded the British Empire Medal Western Australian for thirty-two years of service to the police and community.

William McGregor is a lecturer in linguistics at Bond University. He has made a depth study of Gooniyandi (published in 1990), and undertaken briefer studies of four other Kimberley languages since 1982. He is currently working with Jack Bohemia on the production of a volume of texts relating to Bohemia's experiences as a police tracker.

1 This paper is the product of a series of field-interview type dialogues between Jack Bohemia and Bill McGregor; the monologic parts (all spoken almost entirely by the former) were transcribed into notebooks, and translated into English by the latter, with the assistance of the former. McGregor bears the responsibility for everything but what Bohemia actually said in the original texts. The Australian Institute of Aboriginal Studies is thanked for financing McGregor's field trips, on which this paper is based.

2 Elkin 1938/1974:336-361; Maddock 1972:158-176; Berndt 1964/1977:453-489; and Meggitt 1962:317-330. 


\section{DEATH PRACTICES IN NORTH WEST AUSTRALIA}

context, and I certainly do not wish to claim that members of a culture are always right in their interpretation of their rites, or even that their interpretations are necessarily preferable to, or better than the interpretations of a non-member. I will, however, be suggesting that speakers' accounts, particularly in the form of biographical narratives, can provide important insights, which cannot be ignored by the anthropologist.

In fact, the literature contains very few accounts of the rites of death, and associated taboos, as told by Aborigines themselves. ${ }^{3}$ Accordingly, the main purpose of this paper is to begin filling this gap in the literature, and to publish some accounts of traditional death practices of Aborigines in the southern-central Kimberley region of Western Australia, as told by Jack Bohemia, a member of the Gooniyandi 'tribe' (see map), in his mother tongue, Gooniyandi.

\section{Mode of transcription}

Each text is represented in two written versions. ${ }^{4}$ The first is a transcription of the original spoken Gooniyandi text; this appears on the left-hand, even numbered pages. The Gooniyandi text is divided into lines (each of which represent, roughly, a sentence); these consist of one or more pause units (or stretches of speech between pauses), which are delimited by commas. Pause units usually coincide with tone units, or stretches of speech uttered on a single intonation contour; those few pauses which occur within tone units are indicated by semi-colons. 5

The transcripts also indicate vowel lengthening, by a colon following the vowel. In Gooniyandi, word final vowels are lengthened either to indicate intensity or duration, or to indicate conjunction, 'and'. Another way in which word-final vowels may be modified is by a following period of voiceless articulation; this has been represented by the letter $h$. Such final syllables usually have greater than normal stress, and it seems that the effect is to add emphasis to the word.

For spelling Gooniyandi words I have adopted a phonemic orthography which is similar to the (non-phonemic) orthography which speakers of the language have chosen to use. ${ }^{6}$ This system is fully described by McGregor. ${ }^{7}$ The majority of the letters and digraphs have the expected values. It should be noted, however, that oo symbolises the high back vowel normally written $u$ in Australian languages, and dd represents the apical tap normally written $\mathrm{rr}$ (written with a single $\mathrm{d}$ in the Chestnut-Hudson-Street system).

The texts contain a number of words which are clearly not traditional Gooniyandi words. These are mainly borrowings from English, and most have been assimilated into Gooniyandi phonetics. They have been spelt according to the Gooniyandi system. In a few instances a word of English derivation was pronounced in a more English way (that is, in a

3 Exceptions include Pompy Siddon's 'When a relative died', in Hudson, Richards, Siddon, Skipper et al 1978:44-45, and Roughsey 1984:196-201.

4 Ideally, I believe, two other representations of the texts should be included: one containing interlinear morpheme-by-morpheme translations of the type traditionally provided by linguists, and a second providing a free translation of each text as a whole. However, considerations of space preclude the inclusion of these versions. In their place, I have opted for a final section with a summary and commentary on the texts, which highlights the principal matters raised.

5 For a detailed description of the system of transcription, see McGregor 1986b; a similar system is employed by Muecke, Rumsey and Wirnunmarra 1985.

6 Street and Chestnut 1983.

$1986 \mathrm{a}$. 


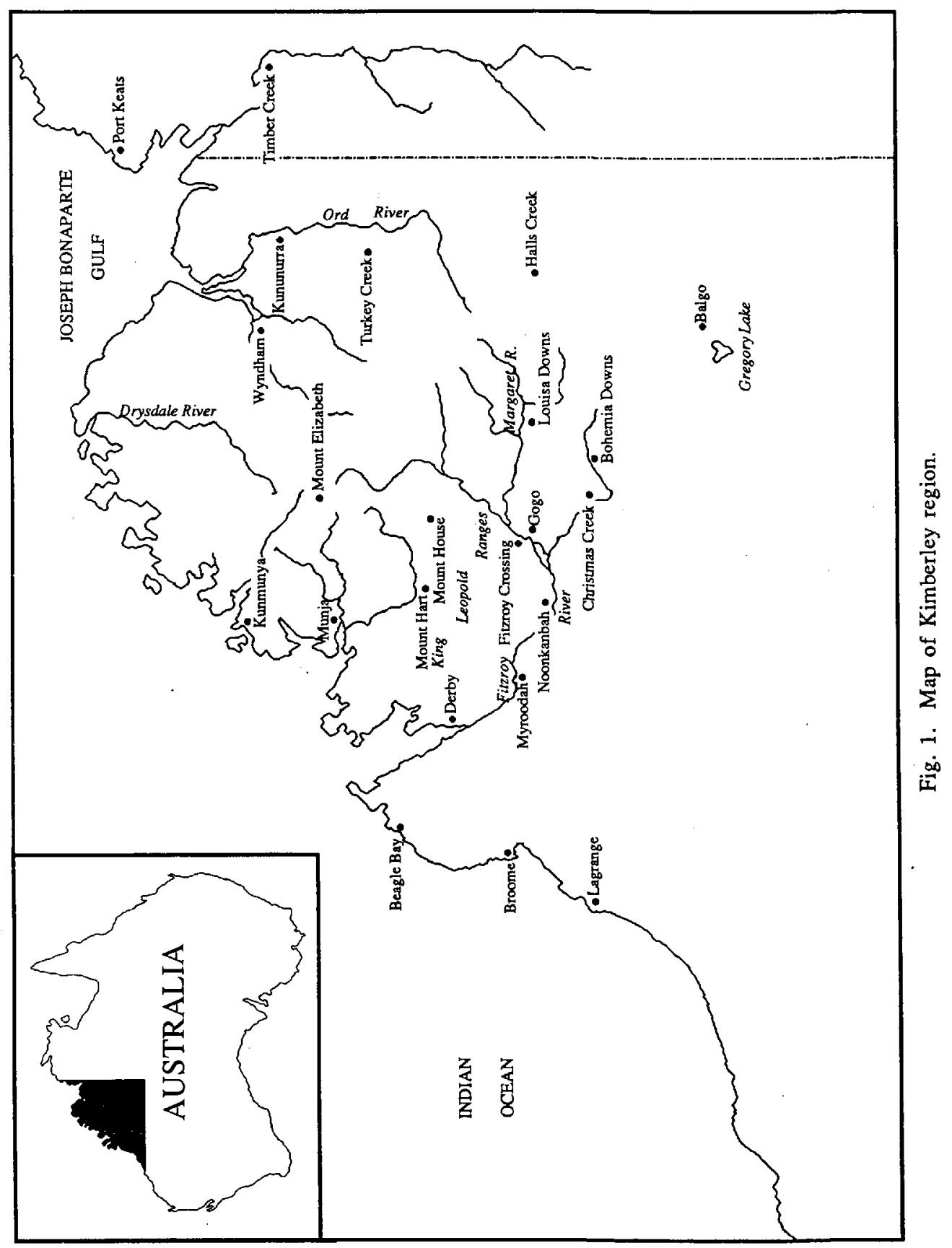




\section{DEATH PRACTICES IN NORTH WEST AUSTRALIA}

way that more closely approximates English phonetics); such words have been spelt either as in standard English (where it is clear that there has been a shift towards that language), or in a phonemically accurate way, using an extended Gooniyandi orthography (where e.g. a non-Gooniyandi sound such as [s] occurs).

Opposite each Gooniyandi line, on the right-hand page, is a 'loose translation' into English - that is, a translation which attempts to preserve the flavour of the original as a spoken utterance. The same conventions are employed throughout this translation as in the original, except that no attempt has been made to represent the lengthening of vowels.

\section{The texts}

The following six texts, and one excerpt from a longer text, were narrated by Jack Bohemia to William McGregor in 1982, during the course of the latter's second field trip to Fitzroy Crossing, investigating the Gooniyandi language. They represent but a small fraction of the corpus of Gooniyandi texts collected by McGregor which mention death and associated rituals or taboos. The six full texts have been chosen because they are all quite short and to the point, and restrict themselves to the themes of death rituals (texts 1 to 5) and taboos (text 6). Although there is a good deal of repetition between the first five narratives (reflecting the commonality amongst performances of the rites) there are also a number of interesting differences of detail, which accounts for the inclusion of them all.

The excerpt (text 7) is included also, because it gives descriptive detail which in places surpasses the detail given in the six full texts. The full story is far too long to include here, and only a small part is relevant to the theme of this paper. In fact, this text is a retelling of a story which had been told a few days previously; in the meantime, I had asked a number of questions of detail about death rites, and this prompted Bohemia to recount a fuller version of the story.

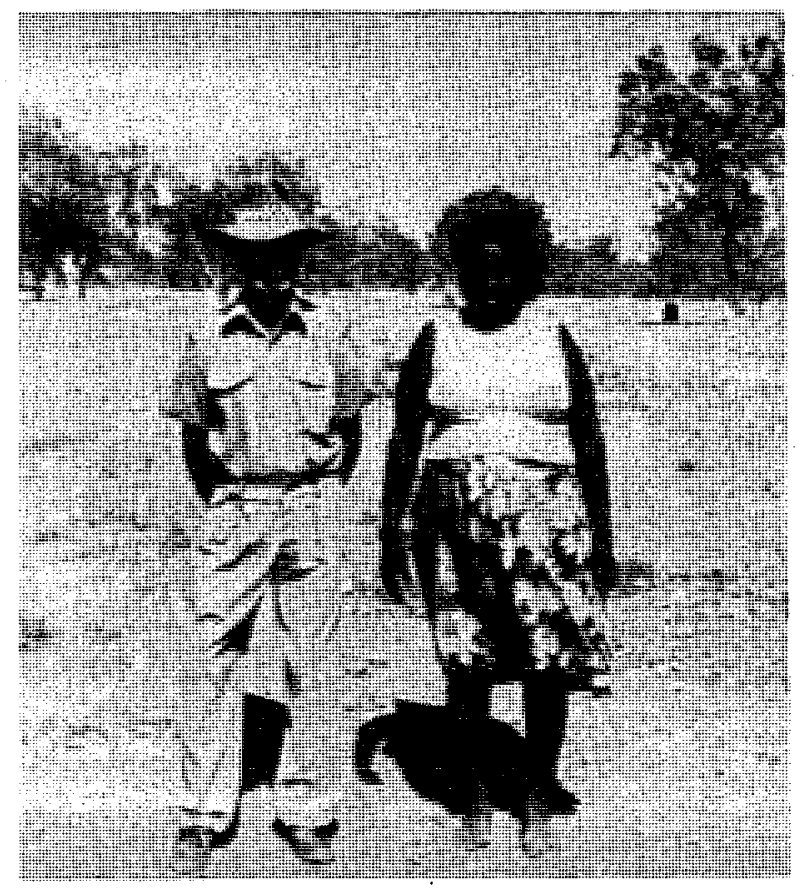

Plate 1: Jack Bohemia in Police uniform, at Fitzroy Crossing Races, 1982, with daughter Daisy. 
Text 1: An inquest

yoowooloo ngamoongamoonhingi, boolgawoolga ngamoongamoonhingi, nyag; maa, garndiwiddiyiddingga; yiganyi garndiwiddingga, yoowoo garndiwiddingga, nyagjawoo, nyagbiddiniyi, yoowooloo, lanygiya (1)

bagiwayi::, milawiddayi:: gijbindi

bajgiwindi thithi, bidi; yiganyinyali bajgiwiddiyi, maroowa

wardbiddiyih, barnbiddiyi; yilba

warangbiddi::; ligoowiddaniwiddangi (5)

goowaa bijngarni, niyaji yoowooloo nangbani

thangarndi, goowaa bijngarniwiddangi

wambah; bidingga yoodbidi; (coughs), yaabjangga; yoo; gamanaya thadbiddaddi

ngaaddi wilajgawoo thadbiddanhi yingingaddi ngaaddi

thadbiddanhi:: wilajga (10)

wamba boolthoogjawindi, wambanyali ligawidda, yanhthooddgjawani, migaya; girili; milawidda

milawidda:: wili, ngaaddi wila; wilajga milawidda:, yoowooloo gamdiwiddi gilbawinbidiyi, yingingaddinyali, ngirndajiyooddoongga; maroowa; nyagbiddini

niyaji, thooddijbiddaddi, nawoomgarni giriliyangga thooddijbiddaddi babiddi

wardbiddah, wayandi jardbidi, garanyi

wamba ligawidda yanhthooddgbani (15)

garanyi dagooddwiddaddinhi yoowoolooya, niyajiya nga; gijaliya

garanyi dagooddwaddiwiddaddi: wila

thirigbidi

ligoowiddaniwiddangi::; garndiwiddi yoowooloo gardbiddaniyi

waddinbiddani (20)

waddinbiddi:: wayandiga ngabbinayi

waddinbiddi:: nangbiddani

garna; garnanaya yoodbinbidiyi

milawinbidda, marlami, wayandiga ngabbinayi

yoowooloo mangaddi; gilbawawidi ngaaddi niyajiya, wilajga; garnanaya, marlami (25)

wayandiga ngabgoonayi yah, migawinmi gamdiwangooddoo

wayandiga ngabbinayi

niyinhingi; marlami galoowinbidiyi, wayandigarni ngabnga

bidi niyajiyooddoo; yaanya, yoowooloo, thardgiyawiddi:: yoodbinbidi doowooya babaabiddi niyaji yilba; mangaddi barnbarngoo ngambiddi, yilba; yoodbinbidiyi (30)

\section{Text 2: Another inquest}

goomboo yoowooloo, goornboo yoowarni, ngila, ngoorndoongoorniya, loowijaya, ngila goolgaddraya (1)

goornboo yoowarni nyagbiddini; yoowarni; garndiwiddingga nyagbiddiniyi, boowooddoonhingingga yoowooloo; gimangarnangga 8

warangji::, ngarlooddja goomboo niyaji waddinbani

milawidda::, wamba goonybidda::, boolthoogbindi, joowoorloo

8 The term gimangarna (literally 'bush dweller') is used to refer to Aborigines who have had (or are believed to have had) little or no contact with whites, and who lead essentially traditional lives. It seems that this term does have some negative connotations, and suggests that the people referred to are unsophisticated. 


\section{DEATH PRACTICES IN NORTH WEST AUSTRALIA}

Text 1: An inquest

olden days people, olden days people, spear; meat, two; maybe two, yes two might spear, they speared him, a man, in the middle of the day (1)

he was lying there, and as they looked he got up

he got up and went, they; they got up and went sneakingly, the murderers

they went, and returned; for good

they waited; they listened for news (5)

news of death arrived, that man had died

word, word of his death came to them

later; they put him; (coughs), some; er; they put him up on a burial platform

they put up stones all around named stones

they stood (stones) up around (10)

while the body burst, they waited, and when it had decomposed, then, the tree, they looked at it

they looked OK, at the stones; they looked around, and discovered the two men, whose names were on rocks, those two; murderers; who speared him

this one, they took him down, the dead body then they took down from the tree

they took it, they lit a fire, in a cooking trench

they waited until it had decomposed (15)

they put hot stones inside the body of the man, in that um; in the dead man

they put a few stones inside his body OK

they covered him up

they listened for news; the two men fell

they fell sick (20)

they were sick the fire having burnt them

they got sick and died

plat; they put the two of them on a tree platform

they looked at them, but nothing, the fire had burnt them

no men, they weren't able to find anyone marked on the rocks there, around; the burial platform, no one (25)

'a fire burnt them,' they said

'a fire burnt the two of them'

then; they found nothing relating to the two, a fire had bumt them

these two; the others, the men, they put these other them up inside a cave

that's for good, they can't go back again, for good; they put them away (30)

\section{Text 2: Another inquest}

people, one woman, in the east, at what-cha-ma-call-it, at Louisa, east at Goolgaddra (1)

one woman they speared; one; two men speared her, men from the north, bush blacks

she was sitting there, and after three days this woman fell ill

they watched, and they waited, until it burst, her stomach 


\section{ABORIGINAL HISTORY $1991 \quad 15: 1$}

wambanyali goonybidda yanhthooddgbani (5)

giriliya wardbiddi, moongaya

milawidda::; yingingaddi gilbawinbidiyi, yoowooloo garndiwiddi, yoowooloo booddoongoonhingi, gimangarna

niyaji wagardi; niyaji; goomboo doowwidda, laandi girilinhingi thooddijbiddaddi

wardbidda:: gooddgoo; widdijbinmi

way; wayandi jardbidi garanyi yoodbidi (10)

garanyi yoodbidinhi:: wili, ba; niyajiya goombooya, ngaandiya babaabiddi

middaya, yoodbidinhi garanyi, ngal; joonbangaddingga

doombinmi, bagiyi

doornbinmi:: wili, bagiyi yilba

niyinhingi ligoowiddani::; boowooddoo gardbiddani gamdiwiddi yoowooloo (15)

boowooddoo waddinbiddiyi:: nangbiddaniyi

briyandiyah, migawinmi yaabja, briyandiya yoodbinbidiyi

yal; booddoongoonhingingga yoowooloo migawinmi, gijangaddingga

briyandiya yoodbinbidiyi, wila bagoowooddiyi

mangaddi; ngambiddi barndaj; aa; mangaddi ngambiddi:, ngoomdoongoornooyoo, barndajbarndajgoo, marlami (20)

wila bagiwiddiddi, wamba bagiwiddiyi

\section{Text 3: A murder at Noonkanbah}

yoowarningga, yoowooloo::, jangala, jangalangga garli, wajbaddi, maningga (1)

thiddi, wajbaddi, limimi; aa: limimiya, man.gaya yalawa, garlingaddingga niyajiya, warawarda: ${ }^{9}$ gardbini

garli yingi baljaddangoo, garli, yingi, baljaddangoo

nag:ganyali gardbini, garlingaddingga

yoowooloo niyaji nangbani (5)

niyaji yoowooloo gardboowidda, mooddoongaddingga, garndiwangooddoongga

gardboowidda yoowooloongga:: wili

yood; yoodbidi niyi gijali, mongayayoo

gijali::, yoowoolooyi::, jambiyind inhingi, jambiyindi

bagiyi, moongaya, wardbidda, gamanaya, thardbiddaddi (10)

ngaaddi, jarndiddi, wilajga, thardgoowa; widdani

ngaaddi; niyi, yingingaddi

yoowooloo; garndiwiddingga, milawiddayi, maroowangaddi yoowooloo:: garndiwiddi, yalawanyali

yalawa; niyajiyanyali mayaroo; waranggilawooddooyoo yoowooloo wàrangbiddi

warangbiddi niyajiya, milawiddaniddi, milawiddayi, garndiwiddingga jimbilangaddingga, nyagbiddini, yiganyingga(15)

yiganyingga; nyagbiddiniyi, jimbilangaddingga

gadbiddini

wardbiddi:: balbiddawinmi; riwiyiddaa

gandiwiddi:: garndiwiddi yoowami, riwi bagiwiddi

yoowami; wik, bagiwiddi (20)

9 Warawarda does not appear in the field transcript, nor is it a word I am familiar with. It was detected during the process of rechecking the transcripts in preparing them for publication. 


\section{DEATH PRACTICES IN NORTH WEST AUSTRALIA}

they waited until her body had decomposed (5)

they went to the tree, one morning

they looked; and found the named stones, of two men, men from the north, bush blacks

this tree(?); this; they got the woman, and took her down from the tree

they took her and a hole; they dug

fir; they lit a fire, and put in hot stones (10)

they put hot stones into her body OK, um; into the woman, inside her body

in her head, they put hot stones, sing; singing songs

they covered her up, lying there

they covered her up OK, and she lay there for good

then they listened for news; the two men fell in the north (15)

in the north the two of them fell sick and died

'in revenge,' the others said, 'they killed them in retribution'

er; the northerners said (that), the Kija men

'they were put down in retribution, and they can remain like that'

no; they won't sneak up again; um; not again, what's it called?, they don't attempt to sneak up on anyone, no (20)

they leave it at that, they let the two of them remain (unavenged)

\section{Text 3: A murder at Noonkanbah}

one, man, a jangala man, jangala man a boomerang, he threw it, one night (1)

in a fight, he threw it, cheek; um in the cheek, close to the ear, with a boomerang there, he hit him

the boomerang was a baljaddangoo boomerang, the boomerang, was named, baljaddanggoo

he killed him dead, with the boomerang

this man died (5)

they belted this man (the murderer), with sticks, everyone

the men belted him OK

put; they put the dead body down, until the next morning

the dead one, a man, was of the jambiyindi subsection, jambiyindi

he remained there, next moming, they took him, on tree burial platform, they put him (10)

rocks, divining rocks, all around, they were standing

rocks; these, had names on them

men; two, they saw him, two murderers, close by

from a nearby homestead, where they lived

they sat there, watching him, they watched him, the two, and with a quartz-tipped spear, they speared him, sneakingly (15)

sneakingly, they speared him, with a quartz tipped spear

they left him

they went and returned; to their camp

five, days they camped

one; week, they waited (20) 


\section{ABORIGINAL HISTORY 1991 15:1}

wikja, aa mandiya, mandiya; girili; milawidda

wardbiddi:: milawidda girili

wilajga milawidda::: wili

gilbawinbidiyi garndiwiddi yoowooloo yingingaddi ngaaddi

wila (25)

laandinhingi waj; biddaddi, (coughs)

babiddi wajbiddaddi, wardbidda; langgagoorliya; yoodbidi

bagiyi langgagoorliya

biddibbidinhi; langgagoorloo, yoodbidi

barngiwiddi, nga; aa ngarloodoo yoowooloo bambiddiddi, yiganyingga ${ }^{10}(30)$

yiganyi; ngarloodoo yoowooloo barnbiddiddi, yaanyaya wik

wayandiya yoodbidi, garanyiya:: wayandiya yoodbidi niyaji yoowooloo, gijali marnawamamawangga

yoodbididdi

bagiyi::h, yoowooloo ngimda garndiwiddi gardbiddaniyi, maroowayooddoo

waddinbiddi:::h, ojbidl.yiddaa balawinbidiyi, derbyyiddaa (35)

derbyya; nangbiddani, ojbidl.ya

ya; niyajiyanyali; derbyya; thirigbinbidiyi, bandaya, wajbalingga goowajgoodda biniril

niyajiya; thirigbinbidiyi, yilba

\section{Text 4: Another murder at Noonkanbah}

thiddinyali gardbiwiddani ya; ngambiddinyali ${ }^{11}$ yaab; ngambiddinyali, thiddi gardbiwiddani, yaabjangga, aa; maningga, maningganyali (1)

yoowooloo:h, yingi booroongbooroong

niyingga gardbini, yaanya; jambiyindinyali

ngajangoowa, mamawa gijali bagiri, ngamoonhingi, and ngajangoowa, ${ }^{12}$ wanggalhmani gardbini broongbroon;ngga, yoowooloo yingi booroongbooroongngga:: gardbini, wanggalhmani

yilbanyali gardbini, gijaliyiddaa (5)

blanketingaddingga doornbinmi; maningga, gijali; moongaya; giriliyayoo, wardbidda thardbiddaddi

wilajga ngaaddi yoodbidi, yingingaddinyali, garnanaya

yoodbidi:: wila

niyaji;nhingi, balbiddawinmi (10)

10 The presence of the ergative postposition on yiganyi 'uncertain' is unusual, since the clause is intransitive (there are however a number of like examples in the corpus of texts, so I do not label the clause as ungrammatical). Note that in the next clause (sentence 31), the ergative does not appear, even though the verb is identical.

11 Ngambiddinyali ('again'-REP) 'again' here alludes to the previous text (text 3), which was uttered immediately prior to text 4 .

12 Note that both the term for the younger brother and the term for the older brother are marked by the genitive (glossed 'his'). This is in keeping with a general principle of Gooniyandi grammar whereby both objects in a frame of comparative reference are taken as the standard of reference - thus, for example, we usually have the equivalent of the other was walking, and the other was standing', rather than 'one was walking. the other was standing' (see McGregor 1984:367). 


\section{DEATH PRACTICES IN NORTH WEST AUSTRALIA}

next week, um on the Monday, on Monday; the tree; they had a look at it they went and looked at the tree

they looked all around OK

they found the two men with their names on the rocks

OK (25)

they threw it (the body) down from above (coughs)

they threw him down, and took him; and in a hollow log; they put him

he lay in the hollow log

they blocked it off; the hollow log, having put him inside

they returned, the; um the three men returned, sneakingly (30)

sneakingly; the three men went back, the next week

they put him in a fire, they put that man in a long cooking trench, the dead man, his brothers

they put him

he lay there, the two men fell sick, the two murderers

they fell sick, and were sent to hospital, to Derby hospital (35)

in Derby; they died, at the hospital

yes; right there; in Derby; they buried them, in the ground, in what white people call a funeral

there; they buried the two of them, for good

\section{Text 4: Another murder at Noonkanbah}

they fought together again; again some; again, they fought together, some people, um; one night, again one night (1)

a man, called Booroongbooroong

he killed him, another; jambiyindi man

the younger brother, whose older brother was dead, some time before, and the younger brother, he was hit in the skull by Booroongbooroong, the man called Booroongbooroong hit him, in the skull

he hit him, to death (5)

they covered him with a blanket; that night, the dead man;

in the morning; to a tree, they took him

they put it up

they put rocks around, named rocks, under the burial platform

they put them around and finished (10) 


\section{ABORIGINAL HISTORY $1991 \quad 15: 1$}

yoowarniya; jaalinyi, milawawinmi, girili niyaji, garnana

garnana; milawawinmi, wardbiddi:: milawawinmi

wilajga milawidda::; marlami, galoowidi, ngaaddi mangaddi; maroowangaddiya

gilbawawidi marlami, galoowidi

niyingga daginyali gardbini (15)

wila thaddgnganhi mooddoo; maroowa marlami, migawinmi garndiwangooddoo yoowooloo mangaddi binaddi mooddooyoo niyaji yoowooloo, gijali, mangaddi binaddi

wanggalhmani; mangaddi wanggalhmani y gardyoonirni, li; ngirnda limi; e:: man.ganhingi

thaanoonggoo gardbini

yilba niyaji gardbini; gijaliyiddaa

aa: wardbidda, thooddijbiddaddi (20)

wardbidda:: langgagooliya yoodbidi

migawinmi wamba, wayandiya yoodbada wamba

barngiwiddi, riwiyiddaa, yaanyaya wik; barn bi; balbiddwinmi

wayandiya yoodbidi, warangji:: wili

niyaji yoowooloo niyajiyanyali gardbani, maroowa (25)

yingi:: booroongbooroong, jagaddanhingi yoowooloo; yi; jagaddanhingi, niyajiya; gardbani bagiyi:: waddinji:: nangbani, niyajiyanyali; moo; noongganbayanyali nangbani mayariya niyimi yoodbidi; garnanaya

gamanaya; laandi, wardbidda:: garnanayayoo, niyaji yoowooloo maroowa

yoodbidi laandi, giriliya (30)

gadbiddini bagiyi wi, wilajga wila yoodbidi

wilajgawoo yoodbidi:: ngaaddi, yingingaddi yingingaddi

gadbiddini, balbiddawinmi yoowooloo, wardbiddi riwiyiddaa

yaanyaya, garndiwiddi; aa ngarlooddja wik; milawawinmi

marlami, galoowidi, mangaddi maroowa gilbawawidi (35)

mangaddi; thawooddawini, marlami

wajbaddi, wajbiddaddi babiddi

wayandiya goolwadawoo, migawinmi, marnawamamawangga, jagaddawamoongga

gamdiwangooddoo marna; jagaddawamoo

wayandiya goolwidi, yi::h, marlami niyinyali wila, maroowa (40)

niyinyali wila maroowa, niyingga gardbini, ngirndajingganyali, ngooddoo yaanya gijali, migawinmi

wila gadbiddini yilba

balbiddawinmi, maya: ligoowi; ligoowiddaniwiddangi::: marlami

marlami ngoomdoongaddiya waddingoowawani:: marlami

niyingganyali wila gardbini, migawinmi (45)

bagiwiddi, warangbiddi yilba, ligoowiddani marlami

mangaddi gardgoowawani yoowooloo, mangaddi wayandiga ngabnga, ngoorndoongaddiya; garndiwiddingaddiya, marlami

niyi wila; maroowanyali; gardbani

Text 5: An unavenged death

thiddi gardboowiddami, ngilayani (1)

gardboowiddarni thiddi, soonookngga, gardbini, wanggalhmani

mangaddi wanggalhmani dagi, jabi gardbini, maningga

jabi gardbini nagganyali, jagaddanhingi yoowooloo, gardbini

yaabjangga; yawanbiddarni, gardboowiddami (5) 


\section{DEATH PRACTICES IN NORTH WEST AUSTRALIA}

then, they went back

after one; month, they were looking, at the tree, at the platform

at the tree platform; they were looking, they went and were looking at it

they looked around; but nothing, they found nothing, no rock; any murderer, they were finding nothing, they found nothing

he had hit him in the right place (15)

'OK he hit him with a hitting stick; there was no murderer,' all the men said

that man didn't know about hitting sticks, the dead man, he didn't know

in the skull, he didn't mean to hit him in the skull, chee; there chee; um, he hit him a little

up from the ear

he hit him for good; to death

um, they took him, and threw him down (20)

they took him and put him in a hollow log

they said 'later, we'll put him in the fire later'

they went back, to their camps, in another week; went back; they returned

they put him in the fire, and left him sitting there

that man fell sick there, the murderer (25)

his name was Booroongbooroong, a jagadda man; a jagadda man, there; he fell sick

he lay there sick and died, right there; Moo; right at Noonkanbah he died there in the homestead

they put him next; on a tree platform

on a tree platform; up, they took him to a tree platform, this murderer

they put him up, in the tree (30)

they left him lying there, having put rocks around

they put rocks around, named rocks

they left him, the men returned, they went back to their camps

another, two; um on the third week; they looked

nothing, they found nothing, they didn't find a murderer (35)

no, the body didn't decompose and mark the stones, nothing

he threw him, they threw him down

'let's try him in the fire,' they said, his brothers, all the jagadda men

his brothers were all; jagadda men

they tried him in the fire, ..., but nothing that was all, he was the murderer (40)

'he himself is a murderer, he killed him, he himself, that other dead man,' they said

OK they left him for good

they returned, um; listen; they listened for word but nothing

no one got ill or anything

'he himself killed someone,' they said (45)

they left it at that, they stopped there for good, having heard nothing

no one fell sick, the fire didn't burn anyone, no one nor two people, nothing

he himself, was a murderer, and had fallen sick

\section{Text 5: An unavenged death}

they fought together, in the east (1)

during the big fight, Snook, hit someone, in the head

not right on the skull, but on the back of the neck he hit him, one night

he hit him dead on the back of the neck, a jagadda man, he killed him

the others; belted one another, fighting together (5) 


\section{ABORIGINAL HISTORY 1991 15:1}

gardboowiddarni:: wili, niyi gardboowidda, mooddoo thaddggilanganhi gardboowidda::: wili

na yoowooloo; no; gijali, bilanggidiya, roolimabbidi, yoodbidi, moongayayoo moongaya, giriliya; yoodbidi, garnanaya ngaaddi; wilajga; yarndili, ngaaddi yarndili, thardbiddani:: wilajga, yingingaddi (10)

gadbiddini, barngiwiddi riwiyiddaa

bagiwiddiddi, jaalinyi garndiwiddiya

milawawinmi; girili

milawidda:::, marlami

yarndili milawidda:: yingingaddi:: marlami (15)

yaabja migawinmi, mangaddi, yilba mooddoo thaddgnganhi

mangaddi ngirnda; booladi; ngaaddi, bagiri, waraari

booladi; ngaaddi; warawooddaaddi

wila; mooddoo ba; thaddgnganhi mooddoo

aa ngambiddi aa milawidda:: marlami (20)

yoodbidi

wayandiya; goolwada, wayandiya goolwada, winhi

wardbidda::, booddoongoo wardbidda, bamaddyayoo riddinggi, biddinhingi; warlibiddiya, riddinggi bamaddya

niyajiya, garanyi::: wayandi::: jardbidi gooddgooya

ngabnga:: wili (25)

garanyingga dagoodddagooddwiddaddinhi, gijaliya

garanyi dagooddwiddaddinhi joorliya, middaya, garanyi dagooddwiddaddinhi ${ }^{13}$

doornbinmi

doombinmi:: wila, gadbiddini

balbiddawinmi, wardbiddi:: riwiya bijbiddarni (30)

ligoowiddani::: marlami, mangaddi yoowooloo gardgoowawani, maroowa

wila mooddoo thaddgnganhi, migawinmi

jaaliyanyi; jaalinyaanyi:: jaalinyaanyi, ligoowiddani marlami

mangaddi gardgoowawiddani; yoowooloo; maroowa

wila mooddoo thaddgnganhi migawinmi (35)

Text 6: Death taboos

marniwa, aa: (1)

W.McG. um

yiganyi, garingoowa, nangbani, ngoombarnawa thithi bajgiyi niyinhingi

gooddmoo; goomooloo riwi gadbini

ward; ward;ji, yaanyaya riwi bagiri, bagiyi (5)

yaanyaya riwi bagiyi, niyinhingi wardji yaanyaya mayaroo;ja; yilba waranggiri

mangaddi barnbarngiri ngambiddi niyajiyiddaa, riwi goomooloo gadbini, garingoowa; nanggilawaninhi

13 Note the contrast between this clause and the immediately previous one (in sentence 26); the two are near minimal pairs. In (26) garanyi 'hot stone' is non-participant Actor - that is, an Instrument - in a clause referring to putting stones in the dead body. In (27), it is a goal of the same process. One might attempt to encapsulate the difference in meaning with the following English translations: 'They filled up (in) the dead man with hot stones' vs. They put hot stones into the dead man's stomach and head'. 


\section{DEATH PRACTICES IN NORTH WEST AUSTRALIA}

they fought together and finished, they belted him, the one who had killed the man with a hitting stick

they belted him and finished

the man; now; the dead man, in a blanket, they rolled him up, they put him down, until the morning

in the morning, in a tree; they put him, on a burial platform

rocks; around; divining stones, divining stones, they put around underneath him, with names (10)

they left him, and went back to their camps

they remained there, for two months

they were looking looked; at the tree

they looked, but found nothing

they looked at the divining stones with names but found no indications (15)

some of them said, 'no, he killed him with a hitting stick'

'no this; dry; stone; it is, it stands'

'dry; the rocks; are standing around'

'OK; hitting stick; he killed him dead with a hitting stick'

they looked again but nothing (20)

they put him down

'in the fire; let's try him, let's try him in the fire, hey?'

they took him, they took him south, towards the side of a hill, on the north side; of the river, on the side of a hill

there, they lit a fire in a hole

it burn away OK (25)

they put hot stones in him, in the dead man's body

they put hot stones in his stomach, in his head, they put hot stones in him

they covered him up

they covered him up OK, and left him

they retumed, and they went back to their camps (30)

they listened for news but nothing, no one fell sick, as a murderer

'right, he killed him with a hitting stick,' they said

another mon ... another month and another month, they waited to no avail

no one fell sick; no person; as murderer

'that's it because he killed the other man with a hitting stick' they said (35)

\section{Text 6: Death taboos}

his older sister, um (1)

W.McG. um

maybe, his wife, died, the husband got up and went from there

bereave; he left the place of bereavement

went; he went, and camps at another place, he camped (5)

he camped at another place, then he went to another homestead, he remains for good

he doesn't go back there, he left the place of bereavement, where his wife; died

he stops for good 


\section{ABORIGINAL HISTORY $1991 \quad 15: 1$}

yilba waranggiri

doonggooloo wardgiri, maa mangaddi ngabga, jaalinyi: ngarloodiya

migaya nganggoodoo maa, nyoongoodda (10)

ngabga maarna, maarni ngabga

doonggooloongaddi ngamoo wardjayi

W.McG. ah

ngimdaji thangarndi, aa:, mangaddi yingi goowajgoo, niyaji gijali, marlami

goon.gaa, ngoombarnawangga goon.gaa (15)

yaabjangga mangaddi yingi goowajgoodda, ngoombarnawangga, ngoombarnawangga mangaddi goowajga, marlami

\section{Text 7: Murder at Leopold Downs}

boolga, waddinbani (1)

waddinji, yoowamiya wik, gamdiwiddi wik, yoowoo, gamdiwiddiya wik, waddinji

ngidi; balbiddayinmi, ngilmangi

wilangi waddinbani, moolbarni; warangjiddi niyajiya moolba

waddinji wilangi, jalngangooddoongga yoowooloo, milawidda, doowwiddanhi jimbila yoowami (5)

niyinhingi wamba, wambanyali bagiyi, waddinji

ligayidda, a:: nangbani

booddoonggoo; wardjidda, garnana, ngarag;jinminhi

laandi, thadjiddaddi, garnanaya

nganyijooloo, thadladdi, barayiddi, nganyi laandi barloondi (10)

laandi, barloondi, jidiblimi, laandi garnanaya; yoodli

bidingga, ngaaddi wilajga, nganyi thoodngani, thoodjiddaniddi ngarloodoo yoowooloo, ngarloodoo thoodjiddaniddi, bandayiddaa, girilinhingi

ngaaddi; wilajga, yoodgoowawidi, yingingaddi ngaaddi, yoowooloongaddi yingi

wilajga thadbiddanhi:: wila

ngirnda yoowooloo, yingingaddinyali thadbiddanhi biyaddwanggoo (15)

wamba bag; niyinhingi bamgiyiddi

bagiyiddi::, ngarlooddja, wik; ngarlooddjaya, barngiyiddi

milayidda girili, girili milayidda:: wili

yoowarni; yoowarni; doownga, yoowarni thawooddwini, ngirndaji; biyaddwanggoo, ngilmanginhingi yoowooloo

milayidda wila (20)

thaanoonggoo baryinmi, jidibbinmi; laandi, bidi bawardbinmi thaanoonggoo

babiddi; wajbiddaddi

doowwidda, gooddoombaya mirdbinmi

booddoonggoo wardbidda::, migawinmingiddangi, gidi balbiddawingginmi, ngirnda wardgidda, doowooyayoo, migawinmi

nga; ngajangoowangajangoowangga wardbiddaddi, wardbiddaddi booddoonggoo (25)

booddoo, ngaaddiya, doowooya yoodbidi babaabiddi

biddibbidinhi ngaaddi

balbiddawinmi 


\section{DEATH PRACTICES IN NORTH WEST AUSTRALIA}

he goes under a meat taboo, he doesn't eat meat, for three months

then they give him meat, and rub him (10)

he eats meat now, meat he eats now

he had been under a taboo before

W.McG. ah (tape recorder turned off briefly)

this word, um, he can't say the name, of the dead person, no

he must remain silent, the husband must remain silent (15)

no one can say the name, none of the husbands (classificatory), the husbands can't say it, no

\section{Text 7: Murder at Leopold Downs}

an old man, fell sick (1)

he was sick, one week, two weeks, yes, two weeks, he was sick

we; we were returning, west

he got sick behind, together; we were sitting together as a big group at that place

he was sick behind, the doctors, they looked at him, and removed a piece of quartz from $\operatorname{him}(5)$

then later, for some time he lay, sick

we waited, and he died

north; we took him, a burial platform, we made for him

up, we put him, on the burial platform

me too, I put him up; we climbed, I climbed up (10)

up, I climbed, and lifted him, up; on the platform, I put him

they, (put) rocks around, I got down, we three men got down, three jumped down, to the ground, from the tree

rocks; around, they put them, named rocks, with names of people

they stood rocks around $\mathrm{OK}$

this man, was named by the stones a man from Biyadd (15)

later lie; then we returned

we waited, three, weeks; on the third week we went back

we looked at the tree, we looked at the tree OK

one; one; it got it, it wet one (stone), this; man from Biyadd, the eastemer

we looked OK (20)

we climbed up, they lifted him up; up, they climbed up

down; they threw him

they got him, and wrapped him up in paperbark

they took him north, and told us, 'go back, we'll take this to a cave,' they said

um; his younger brothers took him, they took him north (25)

north, in a hill, they put him inside a cave

they blocked it with stones

they returned 


\section{ABORIGINAL HISTORY $1991 \quad$ 15:1}

\section{Commentary and conclusions}

Texts 1 to 5 and text 7 are narratives dealing with inquests and subsequent acts of retribution, the first five texts being biographical, the last being autobiographical. A number of interesting observations emerge from these six texts.

(1) Inquests were performed by putting the body of a dead person on a tree platform, below which was placed a circle of stones, each of which represented someone who may have been responsible for the murder. ${ }^{14}$ The body was left for a few months, until it had decomposed. The stones would be examined, and those marked by the exudates of the corpse would indicate the murderer. Text 2 shows that women as well as men were accorded this type of inquest. (Another text explains that inquests were not (normally) performed for young children.)

(2) A recurrent theme is that if death took place at night, the dead body was left wrapped in a blanket until the next morning (see line 10 of text 3 , line 6 of text 4 , and lines 8 and 9 of text 5), when it was placed on the platform.

(3) It is notable that even if someone is witnessed killing another person, an inquest is still held (see texts 3 and 4 ). And as text 3 illustrates, the inquest may identify someone other than the person who actually struck the blow as the one really responsible.

(4) Once the murderer had been determined, action was taken to redress the death. In texts 1 to 5 , sorcery was employed to kill the murderer. This was accomplished by putting hot stones in the corpse; the effect of this was that the person responsible for the death would fall sick, and die. ${ }^{15}$ More direct methods were, of course, also employed. One text describes how a group of relatives of a dead woman travelled over an enormous area, Iracking and eventually killing the murderer. These 'avengers' (or "soldiers", as Jack Bohemia would say) painted themselves in white ochre before going on their expedition; thus their Gooniyandi name is galardingarna, literally 'white ochre dweller'. On the other hand, in text 7, a white agency, the police, was used: the police were informed, and their trackers succeeded in capturing the murderer.

(5) Each of texts 1, 2, 4 and 5 show that an inquest is not always successful. Text 4 and 5 show that; if the inquest fails, the body may still be tried in the fire, as a second inquest. Here, the hot stones are placed in the body, and the bereaved just await for news of someone's death, this person is then held to have been responsible.

(6) The second inquest may or may not be successful. In each of the texts 1,2,4 and 5 there is at least one death for which no murderer is found. In each instance, some reason is advanced for this failure. In texts 1,2 , and 4 , it is because the dead person was in turn responsible for killing someone else; in text 5 it seems to be because the death was accidental (note that the same explanation is given for the failure of the first inquest in text 4).

(7) The corpse is finally disposed of by placing it in a cave, or in a hollow log, the entrance of which is blocked up. According to text 7 , the body is wrapped in paperbark first (see plate 2); this text also indicates that it was the responsibility of the brothers of the deceased to carry the body from the burial platform to the final resting place.

(8) The texts mention another way in which a person may be ensorcelled dead: by magical spearing with a quartz-tipped spear. The ensorcelled person falls sick and finally dies. The actual process is not described in detail in any of the texts, but is alluded to in text

14 See, for example, the photographs in Idriess 1949:98, and 1937:198.

15 Interestingly, this process is what Bohemia understood me to be referring to when I questioned him about pointing the bone. 


\section{DEATH PRACTICES IN NORTH WEST AUSTRALIA}

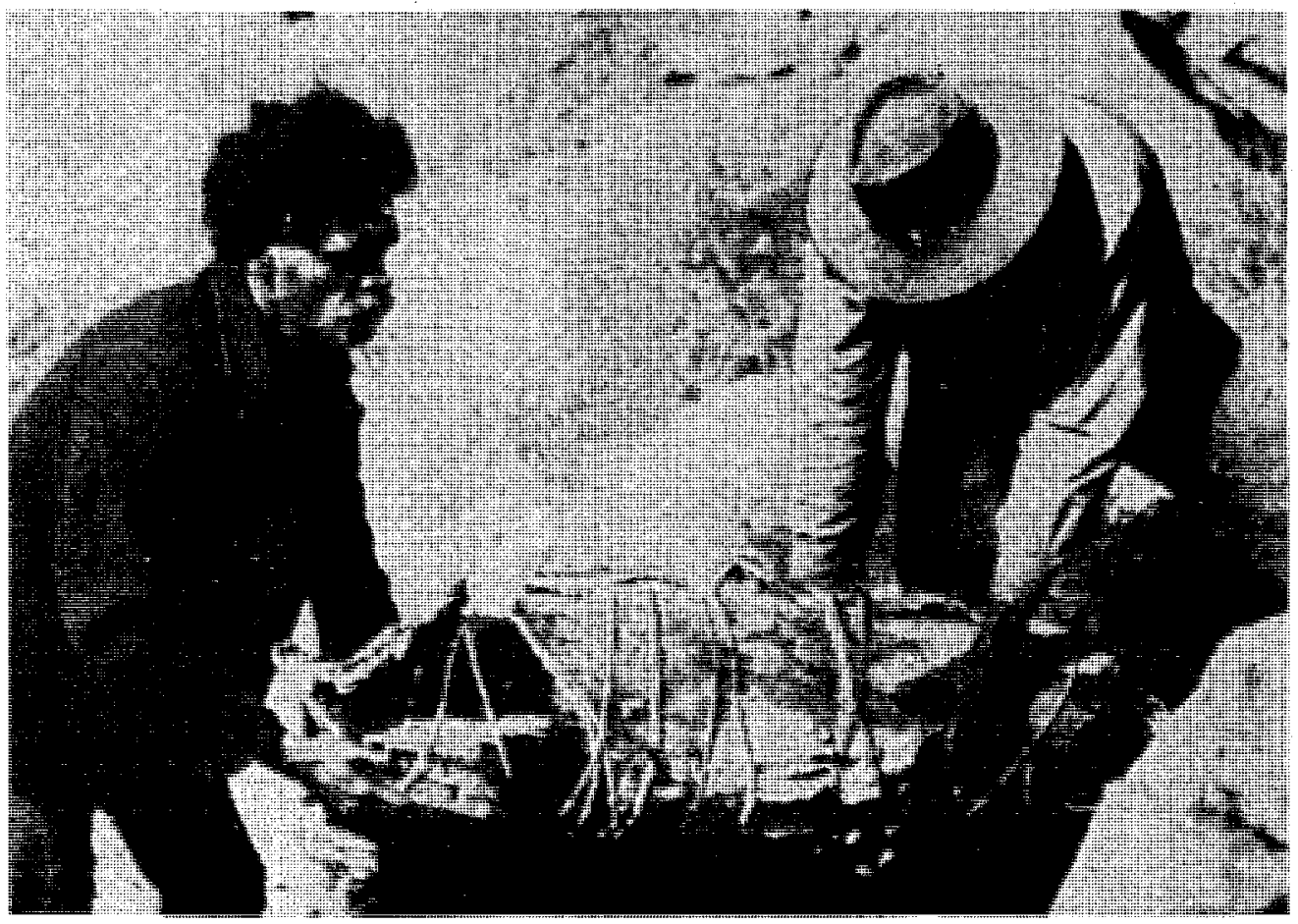

Plate 2: 'Remains of a dead blackfellow'. Courtesy of The West Australian. Published in Western Mail, $22 / 2 / 1940$. 
1 (line 1), text 2 (line 2), and text 3 (lines 13 to 18). In text 7 , we find that the sorcery has been discovered, and the quartz tip removed, but too late; the victim still dies.

Text 6 is expository rather than narrative; it presents a general rather than a particularistic account of the taboos that were placed on relatives of the deceased. Three taboos are mentioned: (a) a proscription on remaining in, and later visiting the place of death of the relative (compare the proscription on returning to the place of burial, mentioned in text 1); (b) enforcement of a taboo on eating meat for some months after the death; ${ }^{16}$ and (c) proscription on uttering the name of the dead person. Reference to all of these can readily be found in the anthropological and linguistic literature.

I have already commented briefly on the anthropological importance of texts such as those included here. I will conclude by mentioning what in my opinion are the most important implications to anthropology.

Firstly, traditional rites and taboos are not practised by the Gooniyandi, and probably have not been for some time. ${ }^{17}$ Inquests are no longer held, and payback killings no longer take place; corpses go immediately into the control of white institutions. (There is some evidence, however, that inquests - albeit not the full rites, with the platform - are still held by desert peoples residing in Fitzroy Crossing.) Even the taboos are rarely observed either rigorously or strongly. Thus the only way of obtaining information relating to the traditional practices is by talking to individuals alive today, who remember the past, or who have heard about it from others. What Jack Bohemia's texts show very clearly is the importance of biographical texts; as we have seen, such texts can reveal where general principles fail. I did on a number of occasions question Jack Bohemia and other Gooniyandi men about death rituals, asking what was done in this or that circumstance; the results were almost invariably generalisations of the type which predominate in text 6 . They did not suggest that the inquests sometimes failed, or why.

Jack Bohemia's silence on certain matters is also, I believe, significant. He does not for instance distinguish in his texts between those rituals performed by Gooniyandi, and those performed by others - although we can in places make good guesses: for example, the Noonkanbah murders (texts 3 and 4) presumably involved Walmajarri people; the Louisa murder (text 2) and Snook's murder (text 5) presumably involved Gooniyandi people (Snook was a Gooniyandi man); and the Leopold murder presumably involved mainly Bunuba people. This could be a reflection of the destruction to traditional life which followed white colonisation; or there may be some other explanation. Furthermore, he takes white interference for granted; for instance, no attempt is made to justify the failure to hold an inquest for the two men who died in Derby (text 3), or to try to obtain the corpse.

16 It is likely that there was a rite surrounding the lifting of the meat taboo - see Hudson et al 1978:45, which describes such a rite in Walmajarri. Bohemia's mention of rubbing (see line 10) is presumably a reference to a similar rite in Gooniyandi. It is not clear in Bohemia's text what is rubbed on the bereaved person; Siddon (Hudson et al 1978:45) says that fat was rubbed over the mouth and face of the bereaved, and it may have been the same in Gooniyandi tradition.

17 Internal evidence suggests that the events described in the texts took place sometime this century. For instance, Snook (see text 5) was a contemporary of Jack Bohemia; mention of sending sick Aborigines from Nookanbah to Derby hospital suggests some fairly recent date, and later in text 7 there is mention of police tracker Joe, who was a famous tracker in the $1920 \mathrm{~s}$ and $1930 \mathrm{~s}$ (see for instance Idriess 1935:76). My hypothesis is that all of the events described took place during the course of Bohemia's lifetime, which is why he is able to provide such detail. 


\section{DEATH PRACTICES IN NORTH WEST AUSTRALIA}

Thirdly, another interesting thing brought out in these texts (usually given short shrift by anthropologists) is the traditional names of various items and actions relating to the particluar field of social action or experience, in this case death. (Not all of these are specific to this aspect of experience.) Such terms give us some notion of the way in which Gooniyandi culture divides up the 'semantic space' of death and death ritual, etc. ${ }^{18}$ Not surprisingly, terms of this type are difficult, if not impossible to elicit formally, in response to English prompts, and in any event, their significance can only be appreciated through examination of textual occurrences. Below I list these terms, in alphabetical order, together with a short explanation:

\section{Term \\ biniril \\ boolthoog- \\ briyandi \\ briyandiya}

doonggooloo

garanyi

garnana

gijali

goomooloo

goon.ga

goowaa

jarndiddi

\section{Explanation}

'funeral'; this term is clearly a borrowing from English, and is used in reference to the burial rites of the dominant culture in Australia.

'burst, of a decomposing corpse'

'in revenge, in turn'

'in revenge'; the difference between briyandi and briyandiya (which presumably involves the LOC postposition) is unclear at present. It seems, however, that briyandi is more usually used as a manner adverbial, relating one event to a previous one (usually mentioned in the immediately preceding text), whereas briyandiya does not normally relate two events in contiguous clauses (see line 19 of text 2).

'taboo'; this term appears to be restricted to the meat taboo enforced on the death of a close relative.

'cooking trench, hot stones'; interestingly, this term is also used in reference to guns, rifles, and bullets.

'tree platform on which a dead body is placed'19

'dead body, dead person, dead'

'bereaved'

'refrain from speaking, speak circumspectly'. This term is used in reference to various situations in which speech should be either avoided, or monitored carefully. The paradigm circumstances for this behaviour are (a) speaking to, about, or in the presence of one's mother-in-law; (b) speaking about the recently dead. Gooniyandi speakers most frequently gloss it 'don't speak'.

'news of a death'

'divining stones'; stones placed under a burial platform in an inquest to find the person responsible for a death' (see also yarndili). ${ }^{20}$

18 cf. Maley 1985.

19 Jack Bohemia referred to this structure as a galbari in his variety of English. This clearly shows the influence of Christianity: it is Bohemia's pronunciation of Calvary, the place at which Christ was crucified.

20 The stones used to divine the person responsible for a death in an inquest are variously called yingingaddi ngaaddi 'named stones', yingingaddi 'with names, named', just plain ngaaddi 'stones', jarndiddi, and yarndili. The last two terms are of interest because they show the well attested correspondences $j$ of Walmajarri (and other Pama-Nyungan languages to the south and south east) with $y$ of Gooniyandi, and dd (=rr) of Walmajarri with l of Gooniyandi (see McGregor forthcoming). It is also noteworthy that the first term, and not the second, occurs in text 3 , which concerns a death at Noonkanbah, which 


$\begin{array}{ll}\text { jimbila } & \text { 'quartz, a quartz spear-tip inserted in a body by sorcery' } \\ \text { ligoo } & \text { 'listen for news of the death of someone who has been ensorcelled' } \\ \text { maroowa } & \text { 'killer, murderer'. Usually given the English gloss 'murderer' by } \\ & \text { Gooniyandi speakers; however, this term contains none of the } \\ \text { implications of intentionality of 'murderer' in English. } & \text { '1 } \\ \text { nawoornga } & \text { 'dead body, dead person' } \\ \text { yanhthooddg- } & \text { 'decompose (of a dead body)' } \\ \text { yarndili } & \begin{array}{l}\text { 'divining stones'; stones placed under a burial platform in an inquest to } \\ \text { find the person responsible for a death' }\end{array}\end{array}$

Many more terms could in principle be added to this list, but these are the main ones mentioned in the texts.

\section{BIBLIOGRAPHY}

Bemdt, M. and H. The world of the first Australians. Sydney, 1964/1977.

Elkin, A.P. The Australian Aborigines. Sydney, 1938/1974.

Hudson, J.E., P. Richards, P. Siddon, P. Skipper et al. The Walmatjari: an introduction to the language and culture. Darwin, 1978.

Idriess, Ion L. Man tracks. Sydney, 1935.

Over the range. Sydney, 1937.

. One wet season. Sydney, 1949.

Maddock, Kenneth. The Australian Aborigines: a portrait of their society. Harmondsworth, 1972.

Maley, Y. The semantic field of homicide, in J.D. Benson and W. Greaves, eds., Systemic perspectives on discourse, vol.2, pp.152-169. Norwood, 1985.

McGregor, William B. A grammar of Kuniyanti, an Australian Aboriginal language of the southem Kimberley, Western Australia. Ph.D. Thesis, University of Sydney, 1984.

. 'Another orthography for Gooniyandi', Australian Aboriginal Studies 1986/2, 1986a:62-5.

- 'Discourse function of intonation in Kuniyanti', Australian Review of Applied Linguistics 9 (1), 1986b:136-49.

. The status of the feature [rhotic] in some languages of the north west of Australia. Forthcoming in Aboriginal Linguistics.

Meggitt, M.J. Desert people. Sydney, 1962.

Muecke, Stephen, Alan Rumsey and Bango Wirrunmarra. 'Pigeon the outlaw: history as texts', Aboriginal History 9, 1985:81-100.

Nash, David. Ethnodialectology in west central Northern Territory. Paper given to Australian Linguistics Society Conference. Brisbane, August 1985.

Roughsey, Elsie. An Aboriginal mother tells of the old and the new. Melbourne, 1984.

Street, David and Topsy Chestnut. 'We spell it 'Gooniyandi': notes on the new Gunian orthography', Australian Aboriginal Studies 2, 1983:78.

Western Mail, Perth, 22 February 1940.

has been a Walmajarri stronghold for a number of years, while the second term, but not the first, occurs in text 5 , which apparently refers to a death at Louisa Downs. This may well be a reflection of the connection between language and place which has been noted by a number of Australianist linguists (e.g. Nash 1985).

See Maley 1985. 